\title{
Application of Radioimmunoassay for Livestock Fertility Management
}

\author{
Sukanta Mondal ${ }^{1 *}$, Sandip R Sardessai ${ }^{2}$ and VP Varshney ${ }^{3}$ \\ ${ }^{1}$ ICAR-National Institute of Animal Nutrition and Physiology, India \\ ${ }^{2}$ Dept. of Physiology, Goa Medical College, India \\ ${ }^{3}$ ICAR-Indian Veterinary Research Institute, India
}

Received: September 23, 2017; Published: October 10, 2017

*Corresponding author: Sukanta Mondal, ICAR-NIANZP, Bangalore, India

\begin{abstract}
Reproductive performance is one of the important factors for determining the economics of livestock production. Reproduction is a complex luxurious process affected by environmental factors and involves a series of physiological processes and supported by endocrine system through release of various hormones A sound knowledge of reproductive functioning in terms of interplay of hypothalamic, gonadotropic and gonadal hormones, with synergistic and antagonistic influences from other hormones and factors involved in the regulation of various reproductive stages, accurate oestrus detection, timely pregnancy diagnosis and early detection of non-conceived stock can be expected to lead to an improvement of the reproductive efficiency. The different phases of reproductive cycle and pregnancy are regulated by intricate sequential events and interactions between hypothalamic releasing hormones, hormones secreted from the pituitary and sex steroids secreted by the ovary. Lack of integration or synchronization or endocrine imbalances at any phase of the sequence may result in reproductive failure. This paper focuses on use of various hormones for detection of estrus and early pregnancy in livestock.
\end{abstract}

Keywords: Reproductive Efficiency; Gonadotropic Hormones; Gonad Hormones; Reproductive Failure.

\section{Introduction}

Assessment of hormones in livestock is widely used to achieve the improvement of both production and reproduction. Conventional ways of (genetic) improvement of livestock are based on selection and crossbreeding programme. These programmes have proved to be very effective, but in general they are time consuming and expensive. Furthermore, heritability estimates are generally very low. For these reasons, much of the current research is directed towards the development of alternative methods of selection, which are based on the correlation between biochemical parameters such as hormones, enzymes, metabolites etc and economically important traits. Much of this type of research has initially been directed to the study of blood types and protein polymorphism in which markers are most likely linked to the action of a single gene or a few genes only. These marker genes may be coupled to other genes which are relevant to economically useful traits, and therefore can be used, in principle, as a basis for selection. Some hormones considered to be possible markers for production traits are thyroid hormones, growth hormone, insulin, prolactin, corticosteroids and androgens. The hormones used for markers of reproductive status are LH, testosterone, progesterone, estrogen, estrogen sulphate etc. An important step towards an improved understanding of reproductive physiology was the introduction of highly specific and sensitive radioimmunoassay technique in the early 1960s. Earlier bioassay methods of hormone estimation were not so much reliable and accurate. Radioimmunoassay (RIA) and other related techniques now a day's allow measurement of hormones and other substances with a sensitivity up to the level of pico gram. Therefore RIA techniques become so popular over the others.

Monitoring Of Fertility By Measurement of Hormones: Measurement of progesterone, estrogen, oestrone sulphate, pregnancy specific protein and pregnancy associated glycoprotein has found practical application as a method for improving reproduction in farm animals.

\section{Expression of estrus}

Poor expression of estrus is one of the major factors hampering the efficient utilization of tropical cows and buffaloes. Estrus is traditionally observed by behavioral symptoms which, however is practically very difficult because the overt signs are of low intensity 
and of short duration. Occurrence of ovulation which is not preceded by overt behavioral estrus symptoms is quite common in tropical animals during stressful summer and non-stressful winter months. Progesterone serves as a marker for determination of functional status of corpus luteum and diagnostic tool for identifying ovarian condition such as estrus confirmation, differentiating types of cysts, silent estrus and lack of cyclicity in cattle and buffaloes. Estrogen is essential for expression of estrus whereas progesterone is required for preparation of uterus for implantation and maintenance of pregnancy. This is because progesterone levels are low around the time of ovulation and high during luteal phase of estrous cycle or during pregnancy and declined to basal level on the day of parturition. Mean plasma progesterone concentration declined from $1.14 \mathrm{ng} / \mathrm{ml}$ on day 4 prior to estrus to less than $0.4 \mathrm{ng} / \mathrm{ml}$ on the day of estrus and then rose to $2.73,1.84 \mathrm{ng} / \mathrm{ml}$ on day 10 and 8 of the cycle in cattle and buffaloes, respectively [1-3] .

Mean progesterone level was lowest on the day of estrus and rose to a peak level during mid luteal phase of cycle which then declined to a basal level on the day of next estrus in cattle and buffaloes that exhibited overt and silent estrus, respectively [4,5]. The overall plasma progesterone levels in cattle and buffaloes that exhibited silent estrus were lower compared to those in overt estrus and might be responsible for poor expression of estrus. Estradiol levels are maximum on the day of estrus and declines gradually with a minimum concentration on day 12-14 of the cycle. In males, testosterone is responsible for sexual maturity and sperm production. In infertile animals or in case of oligospermic animal, testosterone levels remain low or undetectable. The economic benefit of progesterone based estrus confirmation has not been quantified. Since the proportion of cows not in or near estrus when inseminated varies among herds from 0 to $60 \%$ [6], a substancial benefit might be expected, especially on the farms with a high error rate for estrus detection. This benefit should result from reduction in calving interval and the number of inseminations per conception [7] demonstrated a strategy of on farm milk progesterone testing on day 19 after insemination, followed by prostaglandin treatment of non pregnant cows will be profitable, but only if the efficiency of detection of estrus among cows diagnosed non pregnant is increased by more than $20 \%$ and if the error rate in pregnancy is less than $3 \%$. To achieve the latter, the cows which are non pregnant on the basis of on farm progesterone test should be checked again for pregnancy by other methods.

\section{Diagnosis of Pregnancy}

Early detection of pregnant and non-pregnant livestock has become a key to good breeding management because it is an essential factor for monitoring and controlling fertility. Many new and old technologies are available to identify pregnant and nonpregnant animals early post service. The methods of pregnancy diagnosis are divided into direct and indirect methods. The direct pregnancy diagnosis methods include - transrectal palpation and ultra sonography. Pregnancy diagnosis by rectal palpation have been reported during early pregnancy in cattle [8,9], buffalo [10], sheep [11] and pig [12]. Traditionally, to confirm pregnancy at about day 30 of gestation onwards, the practitioners have relied on the palpation of the amniotic vesicle and slipping of the chorioallantoic membranes between the thumb and forefinger. Palpation technique detects pregnancy with an accuracy of 66 to $100 \%$ from Days 49 to 109 of gestation, however it has low accuracy (17 to 57\%) for determining multiple fetuses.

Transrectal ultrasonography has been used for pregnancy diagnosis in cattle [13], buffalo [10-14], sheep [8] and goat [1417]. Transrectal ultrasonography identifies the embryonic vesicle as early as Day 12 after mating but the sensitivity of this technique for pregnancy is very low (12\%) earlier than 25 days after mating. Transrectal ultrasonography for pregnancy diagnosis offers some advantages over palpation per rectum: earlier diagnosis of pregnancy/non-pregnancy, determination of embryo/fetus viability, reduction of misdiagnosis and reduction of "potential" iatrogenic embryo/fetal attrition. The currently available indirect methods of pregnancy diagnosis include measurement of hormones such as progesterone [18-20], estrone sulphate [21,22] and pregnancy specific proteins such as pregnancy-associated glycoproteins [23,24] the early pregnancy factor [25] and interferon-tau [26,27]. Early pregnancy diagnosis will assist dairy producers in managing open cows and improving reproductive performance and economics of their herd.

\section{Progesterone}

Measurement of progesterone by RIA has been widely used for verifying whether cows are in estrus at the time of insemination or early diagnosis of pregnancy in cattle, buffaloes, goats and pigs. Progesterone levels elevate during the mid cycle of each reproductive cycle and during the entire gestation period. If the cow is not pregnant, the corpus luteum regresses and progesterone levels decline to low levels about 2 days before the cow comes into heat again. However, if the cow becomes pregnant, the corpus luteum continues to function and progesterone levels remain high throughout gestation. In pregnant cow, progesterone values in peripheral plasma increase with the development of corpus luteum up to conception (5-10 ng/ml) on days 15-20 after conception; these concentrations remain constant until shortly before parturition. Using progesterone assay pregnancy can be predicted between 68 to $95 \%$ and this test gives best accuracy after three weeks of pregnancy. Studies in the bovine estrous cycle indicate that the milk or serum progesterone concentrations reach a maximum value 1314 days after estrus, and if the animal is pregnant, these continue to remain elevated up to day 21 after fertilization [28] and beyond.

These high levels of progesterone in serum or milk between days 18 and 24 after insemination form the basis of establishment of pregnancy in cattle [29,30]. Since Laing and Heap 1971 first described the use of milk progesterone measurements as an early indicator of the reproductive status of the lactating dairy cow, there has been considerable research on the development of sensitive and reliable assays for progesterone in milk Shemesh et al. [30] proposed that the difference in peripheral plasma progesterone levels between pregnant and non-pregnant cows, 19 days after insemination, can form the basis for a very early pregnancy test. Laing and Heap 1971 first documented this in milk to diagnose cows 
in early pregnancy. Conception extends the life of the corpus luteum (CL) by preventing the luteolytic mechanism from being triggered, thus prolonging and maintaining its functional characteristics, ensuring continued high progesterone levels [31]. In buffalo cows, the progesterone levels in milk are four to five times higher than those in blood plasma [32,18]. Like cattle, buffaloes too can be accurately diagnosed as non-pregnant by determination of plasma progesterone concentrations 21 days after insemination [33] also reported that progesterone concentration in the milk of pregnant buffaloes was significantly higher than that in non-pregnant animals on Day 20 and the difference between the two increased with time after insemination. The detection of non-pregnant animals was $100 \%$ successful at all times but the diagnosis was correct for $66,68,81$ and $83 \%$ of animals tested on Days 20, 24, 28 and 40 respectively and predicted as pregnant.

Shemesh[30] 18-22 day reported that plasma and milk progesterone concentrations in pregnant sheep 1822 days after mating were similar, about $3.7 \mathrm{ng} / \mathrm{ml}$ whereas values in nonpregnant sheep were less than $1 \mathrm{ng} / \mathrm{ml}$. The accuracy was 92$100 \%$ for ewes diagnosed non-pregnant in the breeding season, but for ewes tested in the non-breeding season the diagnosis of non-pregnancy according to milk progesterone levels was only 50\% accurate. Progesterone concentrations decrease sharply during regression of the corpus luteum $(\mathrm{CL})$ in the non pregnant doe (one or two days prior to estrus) and return to higher levels within four days following estrus [34-36]. The pregnant doe has high progesterone concentrations during the same time period since the CL does not regress. Recently, Mondal, et al. [37] observed that plasma progesterone concentration declined from day 25 pre partum abruptly to the day of kidding and remained at basal level up to day 25 postpartum in Black Bengal goats.

\section{Estrone sulphate}

Estrone sulphate is a conjugated estrogen that can be detected in maternal plasma, serum, milk and urine. It is produced by the feto maternal axis or the conceptus and its presence is indicator of pregnancy. Actually the viability of fetus is determined by measurement of estrone sulphate. It is detected at day 72 in plasma and between 105-112 days of gestation in milk of cows. Estrone sulphate test can reliably be used to diagnose the pregnancy beyond day 100 of gestation. This test can also be used to diagnose both singlet and multiple calf pregnancies after 110 days of pregnancies. Estrone sulphate test can reliably be used to diagnose the pregnancy beyond day 100 of gestation. This test can also be used to diagnose both singlet and multiple calf pregnancies after 110 days of pregnancies. Estrone sulphate in milk of cows rises from $30 \mathrm{pg} / \mathrm{ml}$ to $151 \mathrm{pg} / \mathrm{ml}$ in whey between days 41 and 60 of gestation to reach a maximum concentration of about $1000 \mathrm{pg} / \mathrm{ml}$ at days 220-240 of pregnancy [37]. Examination of the ranges of ES concentrations in milk sampled from non-pregnant and pregnant cows indicated that all non-pregnant cows and $46 \%$ of cows $<120$ days pregnant had milk ES concentrations $<125 \mathrm{pg} / \mathrm{ml}$. However, only $4 \%$ of cows $\geq 120$ days pregnant had milk ES concentrations $<125 \mathrm{pg} / \mathrm{ml}$. The levels of estrone sulphate in different maternal body fluids, namely, milk and blood plasma, can be utilized as the criteria for confirming pregnancy by after 110 day insemination in bovine species [38].

In Murrah buffaloes the levels of of estrone sulphate were below detection levels $(<50 \mathrm{pg} / \mathrm{mL})$ during the first two months, followed by sharp increase in the fourth month and values stabilized after reaching the highest levels in the sixth month of pregnancy [39]. Hung and Prakash recorded a progressive increase in estrone sulfate concentrations in buffalo plasma after the $4^{\text {th }}$ or $5^{\text {th }}$ month of pregnancy. In an another study by Tsang [40], estrone sulphate was detectable around Day 70 of gestation with value ranging between 0.1 to $0.7 \mathrm{ng} / \mathrm{ml}$, then its level increased steadily till 2 days before parturition when an upsurge was seen (15-50 ng/ml). On Day 85 of gestation, there was a significant difference in the level of estrone sulphate between pregnant and non-pregnant ewes. In goat, oestrone sulphate concentrations began to rise from about Day 40 and reached a plateau of about $19 \mathrm{nmol} / \mathrm{l}$ by Day 120 [41]. This value was maintained until about 20 days pre partum when there was a slight decline in concentration, rising by 2 -fold about 24 $\mathrm{h}$ before parturition. The accuracy for detection of non-pregnancy was only $44 \%$ whilst for detection of pregnancy it was $87.9 \%$ using the cut-off value of $0.1 \mathrm{ng} / \mathrm{ml}$ [42]. Estrone sulphate based on farm pregnancy diagnosis is also possible in foecal sample of pigs. The concentration of total unconjugated oestrogens and estrone are consistently higher between days 24 and 30 in pregnant sows compared to non pregnant sows [43].

\section{Pregnancy associated glycoprotein (PAG)}

Pregnancy-associated glycoproteins (PAG) belong to a large family of inactive aspartic proteinases expressed by the placenta of domestic ruminants including cows, ewes, and goats [44]. PAG are synthesized by the mono- and binucleate trophoblastic cells of placenta and some of them are secreted in maternal blood from the moment when the conceptus becomes more closely attached to the uterine wall and formation of placentomes begins [45]. Among these glycoproteins, Butler, et al. [46] detected two pregnancy-specific proteins in the sera of pregnant cows $-65-70 \mathrm{kDa}$ and a $47-53 \mathrm{kDa}$ protein. Of these, the former showed an immune reaction similar to that of a 1-fetoprotein, while the latter showed no reactivity with known proteins and it was given the name "protein B" or the "pregnancy-specific protein B" (PSPB) in bovines. Pregnancyspecific protein-B (PSPB) was the first pregnancy-specific marker identified in cattle [46] and was later found to have the same $\mathrm{N}$-terminal amino acid sequence as bovine PAG-1. The PAG family were isolated from cotyledons of cow [47-49], ewe [47,50], goat [51] and buffalo [52].

Development of specific RIA and EIA for the presence of pregnancy associated proteins of feto-placental origin in the maternal serum 3-4 wks after conception has been used as a serological marker for pregnancy diagnosis in cattle [53], sheep and goats [54]. During gestation of cow, the concentrations of PAG are detectable as early as from the $19^{\text {th }}$ to $22^{\text {nd }}$ days after the conception, to reach concentrations from 3 to $6 \mathrm{ng} / \mathrm{ml}$ in the neighborhoods of the $33^{\text {rd }}$ to $37^{\text {th }}$ days of gestation $[55,56]$ reported that PAG concentrations increased continuously from day 20 of 
pregnancy until day 240 followed by a dramatic increase in the last ten days of pregnancy with maximum concentrations between day 5 and day 1 prepartum. In the bovine species, two different patterns of expression were found - those PAG that are expressed predominantly in binucleated cells (PAG 1-subgroup) are invariably absent in term placenta, whereas those PAG expressed more uniformly throughout trophoectoderm (PAG 2-subgroup) are detectable at all stages of pregnancy [57]. For example, boPAG-9 is expressed predominantly in early pregnancy, being detectable at Day 25 and declining as pregnancy progresses until being undetectable at term. On the contrary, boPAG-1 is not detectable at Day 25 but becomes prevalent at later stages, although it is absent in term placenta. Bovine PAG-2, $-8,-10$, and -11 are detectable throughout gestation and they are the only PAG present in term placenta. PAG measurement has also been used in several studies to monitor pregnancy failure during the late embryo and early foetal period $[53,58]$.

In sheep the plasma PAG profiles are characterized by an initial increase between the $3^{\text {rd }}$ and $4^{\text {th }}$ week, followed by further gradual rise up to the $9^{\text {th }}$ week of pregnancy [59]. Between the $9^{\text {th }}$ and the $19^{\text {th }}$ week the level remained constant, thereafter a drastic surge occurs, reaching a peak at parturition. Recently Rovani et al. [54] detected pregnancy accurately using bovine ELISA kit in sheep 33 days following mating, while PAGs levels from the previous gestation are no longer detected from 21 days postpartum. The accuracy of the ELISA test was $96.1 \%$ from 33 days of pregnancy until lambing. In goat's perusal of literature revealed a different profile of PAG with a significant first increase between day 21 and day 28 and maximum levels between the $5^{\text {th }}$ and $8^{\text {th }}$ week of pregnancy. Thereafter, PAG levels decreased slowly until parturition [17] reaching basal levels in the $4^{\text {th }}$ week postpartum. Recently [57] was able to diagnose pregnancy in Boer goats from day 28 of pregnancy onwards using an ELISA based on antibodies raised against caprine or ovine PAG. With the antibody rose against caprine PAG a steep increase to a peak level of $69 \pm 9 \mathrm{ng} / \mathrm{ml}$ on day 56 of pregnancy was followed by a gradual decline to $16 \pm 3 \mathrm{ng} / \mathrm{ml}$ at parturition and $0.3 \pm 0.07 \mathrm{ng} / \mathrm{ml}$ four weeks postpartum. With antibovine PAG, the PAG level increased to a maximum of $3.1 \pm 0.2 \mathrm{ng} /$ $\mathrm{ml}$ on day 105 of pregnancy and fluctuated around $3 \mathrm{ng} / \mathrm{ml}$ until the end of pregnancy suggesting its ability to diagnose early pregnancy and its possible use to evaluate feto-placental well-being $[60,61]$.

\section{Interferon-Tau}

In ruminants, the anti luteolytic hormone for pregnancy recognition and maintenance of functional corpora lutea (CL) is interferon tau (IFN- $\tau$ ) [62,63]. It is secreted in large quantities by the mononucleate cells of the trophectoderm as the blastocyst begins to elongate at about days 13 in cattle with a peak production when the concepts reaches its maximal size [64]. The secretion of IFN- $\tau$ by mononuclear cells of the ovine trophectoderm is developmentally regulated with onset of secretion occurring as large spherical blastocysts transition to tubular and elongated filamentous forms between days 10 and 21 of pregnancy. In sheep, it is secreted between days 10-21 by the mononuclear trophoblast cells. On days 11-16, the $\mathrm{PGF}_{2 \rrbracket}$ concentrations are the same in pregnant and non-pregnant animals, but pregnant animals administered $\mathrm{PGF}_{2 \rrbracket}$ on day 19 or 20 do not return to estrus. It is the pregnancy recognition hormone in sheep and other ruminant that acts to silence the transcription of estrogen receptor alpha (ESR1) and, therefore, ESR1-dependent expression of the oxytocin receptor (OXTR) gene in both uterine LE and superficial glandular epithelium (sGE), hereafter referred to as LE/sGE.

This abrogates development of the endometrial luteolytic mechanism that requires oxytocin-induced release of luteolytic pulses of prostaglandin $\mathrm{F}_{2 \alpha}$ (PGF) by uterine LE/sGE; however, circulating concentrations of PGF are greater in pregnant than cyclic ewes due to continued expression of prostaglandin endoperoxide synthase 2 (PTGS2). IFN- $\tau$ is a member of the Type I IFN family that acts differentially on the endometrial luminal epithelium (LE), glandular epithelium (GE) and stroma to regulate expression of a number of IFN-stimulated genes (ISGs) that are hypothesized to play roles in the endometrial differentiation and conceptus implantation [65-68]. It has been demonstrated that bIFN- $\tau$ has several effects on the endometrium that result in decreased PGF $2 \alpha$ secretion in the pregnant cow and maintenance of the CL. For example, IFN- $\tau$ reduces estradiol receptor number and thus prevents an estrogeninduced increase in oxytocin receptor number [69-74]. Moreover, rbIFN- $\tau$ inhibits the oxytocin- and/or phorbol ester-induced increase in phospholipase A2, cyclooxygenase- 2 and prostaglandin F synthase expression in bovine endometrial cells.

\section{Conclusion}

Exploration of fundamental endocrine involvement in reproductive processes is essential for optimum reproductive management strategies and paradigm to overcome the infertility in domestic ruminants. Reliable techniques for early detection of pregnancy aid in culling or rebreeding of animals and provide a valuable tool for controlled breeding programs. Traditional methods of visual observation, abdominal palpation, service records and non-return to estrus are not reliable means of diagnosing early pregnancy. The review has lime lighted the use of hormonal assays for detection of estrus and early pregnancy in cattle, buffalo, sheep, goat and pig with their accuracy. It is concluded that micro quantitation of hormones has come as a revolutionary breakthrough in understanding animal reproduction function and is an important research tool for augmenting both production and reproduction of domestic animals.

\section{References}

1. Mondal S, Prakash BS (2003a) Assessment of ovarian activity in buffaloes by monitoring plasma progesterone profiles. Proceedings of $4^{\text {th }}$ Asian Buffalo Congress, USA.

2. Mondal S, Prakash BS (2003b) Peripheral plasma progesterone concentration in relation to estrus expression in Sahiwal cows. Indian Journal of Physiol. Pharma 47(1): 111-114.

3. Mondal S, Prakash BS, Palta P (2003) Relationship between peripheral plasma inhibin and progesterone concentrations in Sahiwal cattle (Bos indicus) and Murrah buffaloes (Bubalus bubalis). Asian-Australasian. Journal of Animal Science 16(1): 6-10.

4. Mondal S, Prakash BS (2003c) Peripheral plasma progesterone concentration in relation to estrus expression in Murrah buffalo (Bubalus bubalis). Indian Journal Animal Sciences 73(2): 292-293. 
5. Mondal S, Prakash BS (2003) Use of plasma progesterone for monitoring the fertility status of Sahiwal cattle (Bos indicus). Compendium of Society of Animal Physiologists of Indiapp 43.

6. Reimer TJ, Smith RD, Newman SK (1985) Management factors affecting reproductive performance of dairy cows in northeastern United States. Journal of Dairy Science 68: 963-972.

7. Oltenacu PA, Ferguson JD, Lednor AJ (1990) Economic evaluation of pregnancy diagnosis in cattle : a decision analysis approach. Journal of Dairy Science 73: 2826-2831.

8. Roberts SJ (1971) Veterinary Obstetrics and Genital Diseases (2 ${ }^{\text {nd }}$ edn) Ithaca.

9. Youngquist RS (1997) Pregnancy diagnosis. In: Current Therapy in Large Animal Theriogenology, ( $1^{\text {st }}$ edn $)$ 295-303.

10. Pawshe CH, Appa Rao, KBC, Totey, S M (1994) Ultrasonographic imaging to monitor early pregnancy and embryonic development in the buffalo (Bubalus bubalis). Theriogenology 41(3): 697-709.

11. Balke JM, Elmore RG (1982) Pregnancy diagnosis in swine: A comparison of the technique of rectal palpation and ultrasound. Theriogenology 17(3): 231-236.

12. Keel-Diffey SJ (1963) Pregnancy diagnosis in swine. Vet Rec 75: 464.

13. Curran S, Pierson RA, Ginther OJ (1986) Ultrasonographic appearance of the bovine conceptus from days 20 through 60. Journal of the American Veterinary Medical Association 189(10): 1295-1302

14. Awasthi1 MK, Khare A, Kavani FS, Siddique GM, Dhami AJ (2011) Early pregnancy diagnosis in water buffaloes using transrectal ultrasonography. Indian Journal of Animal Reproduction 32(1): 43-46.

15. Buckrell BC (1988) Application of ultrasonography in reproduction in sheep and goats. Theriogenology 29: 71-84.

16. Martinez MF, Bosch P, Bosch RA (1998) Determination of early pregnancy and embryonic growth in goats by transrectal ultrasound scanning. Theriogenology 49: 1555-1565.

17. Gonzales F, Cabrera F, Batista M, Rodriguez N, Alamo D, et al. (2004) A comparison of diagnosis of pregnancy in the goat via transrectal ultrasound scanning, progesterone and pregnancy-associated glycoprotein assays. Theriogenology 62: 1108-1115.

18. Batra SK, Arora RC, Bachlaus N, K Pandey RS (1979) Blood and milk progesterone in pregnant and nonpregnant buffalo. Journal of Dairy Science 62(9): 1390-1393.

19. Kaul V, Praska BS (1994) Application of milk progesterone estimation. Trop Anim Health Prod 26(83): 187-192.

20. Srilatha B, Naidu G V, Srinivas M, Devi Prasad V (2016) Qualitative evaluation of early pregnancy using Rapid detection milk kit in Graded Murrah buffalo cows. Journal of Science 7: 68-71.

21. Hung NN, Prakash BS (1990) Influence of gestation on blood plasma concentrations of oestrone and oestrone sulphate in Karan Swiss cows and Murrah buffaloes. Br Vet J 146(5): 449-456.

22. Prakash BS, ML Madan (1993) Influence of gestation on oestrone sulphate concentration in milk of zebu and crossbred cows and murrah buffaloes. Tropical Animal Health and Production 25(2): 94-100.

23. Butler JE, Hamilton WC, Sasser RJ, Ruder CA, Haas GM, et al. (1982) Detection and partial characterization of two bovine pregnancy-specific proteins. Biology of Reproduction 26: 925-33.

24. Ledezma-Torres RA, Beckers JF, Holtz W (2006) Assessment of plasma profile of pregnancy-associated glycoprotein (PAG) in sheep with a heterologous (anti-caPAG 55+59) RIA and its potential for diagnosing pregnancy. Theriogenology 66: 906-912.

25. Mavedati O, Abdolreza Rastegarnia, Reza Habibian, Yousef Nasiri Bari, Esmail Bandarian (2013) Early Pregnancy Diagnosis in Water Buffalo by Early Pregnancy Factor Measurement Using Rosette Inhibition Test. Global Veterinaria 10 (4): 391-393.
26. Spencer TE, Bazer FW (1996) Ovine interferon tau suppresses transcription of the estrogen receptor and oxytocin receptor genes in the ovine endometrium. Endocrinol 137: 1144-1147.

27. Saugandhika S, Malik HN, Singhal DK, Singhal R, Dubey A, et al. (2013) Identification of the relatively predominant buffalo Interferon tau isoform and its expression in Escheria Coli. Reprod Fertil Dev 26(1): 174-174.

28. Parkinson, TJA Turvey, LJ Jenner (1994) A morphometric analysis of the corpus luteum of the cow duringtheestrouscycle and early pregnancy. Theriogenology 41(5): 1115-1126.

29. Sasser RG, CA Ruder (1987) Detection of early pregnancy in domestic ruminants. Journal of Reproduction and Fertility.Supplement 34: 261271.

30. Shemesh, MN Ayalon, HR Lindner (1973) Early pregnancy diagnosis based upon plasma progesterone levels in the cowandewe. Journal of AnimalScience 36(4): 726-729.

31. Spencer, TENH Ing, TL Ott (1995) Intrauterine injection of ovine interferon-tau alters oestrogen receptor and oxytocin receptor expression in the endometrium of cyclic ewes. Journal of Molecular Endocrinology 15(2): 203-220.

32. Kamboj M, BS Prakash (1993) Relationship of progesterone in plasma and whole milk of buffaloes during cyclicity and early pregnancy. Tropical Animal Health and Production 25(3): 185-192.

33. Singh A, Puthiyandy R (1980) Estimation of progesterone in buffalo milk and its application to pregnancy diagnosis. Journal of Reproduction and Fertility 9: 89-93.

34. Thibier M, Pothelet D, Jeanguyot N, de Montigny G (1981) Estrous behavior, progesterone in peripheral plasma and milk in dairy goats at onset of breeding season. J Dairy Sci 64(3): 513-519.

35. Thorburn GD, Schneider W (1972) The progesterone concentration in the plasma of the goat during the oestrous cycle and pregnancy. J Endocrinol 52: 23-36.

36. Ott RS, Nelson DR, Hixon JE (1980) Peripheral serum progesterone and luteinizing hormone concentrations of goats during synchronization of estrus and ovulation with prostaglandin F2a. Am J Vet Res 41: 14321434.

37. Mondal S, Minj A, Pathak MC, Singh DN, Varshney VP (2014) Importance of hormonal changes during the periparturint period in Black Bengal goats. International Journal of Clinical and Experimental Physiology $1(1): 20-25$.

38. Henderson KM, Karanikolas M, Kenealy L, MacMillan KL (1992) Concentrations of oestrone sulphate in milk during pregnancy in dairy cows. Proceedings of the New Zealand Society of Animal Production 52: 17-19.

39. Henderson KM, Karanikolas M, Kenealy L, MacMillan KL (1992) Concentrations of oestrone sulphate in milk during pregnancy in dairy cows. Proceedings of the New Zealand Society of Animal Production 52: 17-19.

40. Tsang CPW (1978) Plasma levels of estrone sulphate, free estrogens and progesterone in the pregnant ewe throughout gestation. Theriogenology 10: $97-110$.

41. Hamon MH, RB Heap (1990) Progesterone and oestrogen concentrations in plasma of Barbary sheep (aoudad, Ammotragus lervia) compared with those of domestic sheep and goats during pregnancy. J Reprod Fert 90: 207-211.

42. Worsfold A, Chamings RJ, Booth JM (1986) Measurement of estrone sulphate in sheep plasma as a possible indicator of pregnancy and the number of viable fetuses present. British Veterinaty Journal 142: 195197.

43. Choi HS, Kiesenhofer E, Gantner H, Hois J, Bamberg E (1987) Pregnancy diagnosis in sows by estimation of estrogens in blood, urine or faeces. Animal Reproduction Sciences 15: 209-216. 
44. Haugejorden G, S Waage, E Dahl, K Karlbert, JF Beckers, et al. (2006) Pregnancy associated glycoproteins (PAG) in postpartum cows, ewes, goats and their offspring. Theriogenology 66: 1976-1984.

45. Wooding FB (1992) Current topic: the synepitheliochorial placenta of ruminants: binucleate cell fusions and hormone production. Placenta 13: 101-113.

46. Butler JE, Hamilton WC, Sasser RG, Ruder CA, Hass GM, et al. (1982) Detection of partial characterization of two pregnancy specific proteins. Biological Reproduction 26: 925-933.

47. Xie, S, BG Low, KK Kramer, RJ Nagel, RK Anthony, et al. (1991) Identification of the major pregnancy-specific antigens of cattle and sheep as inactive members of the aspartic proteinase family. Proc Natl Acad Sci 88: 10247-10251.

48. Sousa NM, Ayad A, Beckers JF, Gajewski Z (1996) Pregnancy associated glycoproteins. J Physiol Pharmacol 57(8): 153-171.

49. Klisch K, Sousa NM, Beckers JF, Leiser R, Pich A (2005) Pregnancyassociated glycoprotein -1, -6, -7 and -17. Mol Reprod Dev 71: 453-460.

50. El Amiri B, Remy B, De Sousa NM, Beckers JF (2004) Isolation and characterization of eight pregnancy-associated glycoproteins. Reprod Nutr Dev 44: 169-181.

51. Garbayo JM, Remy B, Alabart JL (1998) Isolation and partial characterization. Biol Reprod 58: 109-115.

52. Barbato O, Sousa NM, Klisch K (2008) Isolation of new pregnancyassociated glycoproteins. Research in Veterinary Science 85: 457-466.

53. Szenci O, Beckers JF, Sulon J, Bevers MM, Börzsönyi L, et al. (2003) Effect of induction of late embryonic mortality on plasma profiles of pregnancy associated glycoprotein 1 in heifers. The Veterinary Journal 165(3): 307313.

54. Humblot P, deMontigny G, Jeanguyot N, Tetedole F, Payen B, et al. (1990) Pregnancy specific protein $B$ and progesterone concentrations in French Alpine goats throughout gestation. Journal of Reproduction Fertility 89: 205-212.

55. Perényi ZS, Szenci O, Sulon J, Drion PV, Beckers JF (2002) Comparison of the ability of three radioimmunoassay to detect pregnancy-associated glycoproteins in bovine plasma. Reproduction in Domestic Animals. 37: 100-104.

56.Zoli AP, LA Guilbault, P Delahaut, WB Ortiz, JF Beckers (1992) Radioimmunoassay of a bovine pregnancy-associated glycoprotein in plasma: Its application for pregnancy diagnosis. Biol Reprod 46: 83-92.

57. Green JA, S Xie, X Quan, B Bao, X Gan, et al. (2000) Pregnancy-associated bovine and ovine glycoproteins exhibit spatially and temporally distinct expression patterns during pregnancy. Biol Reprod 62: 1624-1632.

58. López-Gatius F, Hunter RHF, Garbayo JM, Santolaria P, Yániz J, et al (2007) Plasma concentrations of pregnancy-associated glycoprotein-1 (PAG-1) in high producing dairy cows suffering early fetal loss during the warm season. Theriogenology 67: 1324-1330

59. López-Gatius F, Hunter RHF, Garbayo JM, Santolaria P, Yániz J, et al (2007) Plasma concentrations of pregnancy-associated glycoprotein-1 (PAG-1) in high producing dairy cows suffering early fetal loss during the warm season. Theriogenology 67: 1324-1330.
60. Rovani MT, Cezar AS, Rigo ML, Gasperin BG, Júnior J E, et al. (2016) Evaluation of a bovine pregnancy-associated glycoprotein enzymelinked immunosorbent assay kit for serological diagnosis of pregnancy in sheep. Ciência Rural, Santa Maria 46(2): 362-367.

61. Shahin M, Friedrich M, Gauly M, Beckers JF, Holtz W (2013) Pregnancyassociated glycoprotein (PAG) pattern and pregnancy detection in Boer goats using an ELISA with different antisera. Small Ruminant Research 113: 141-44.

62. Bazer FW, Wu G, Johnson GA, Kim J, Song G (2011) Uterine histotroph and conceptus development: select nutrients and secreted phosphoprotein 1 affect mechanistic target of Rapamycin cell signaling in ewes. Biology of Reproduction 85(6): 1094-1107.

63. Bazer FW (2013) Pregnancy recognition signaling mechanisms in ruminants and pigs. Journal of Animal Science and Biotechnology 4(1): 23-34.

64. Guillomot M (1995) Celular interactions during implantation in domestic ruminants. Journal of Reproduction and Fertility 49: 39-51.

65. Hansen TR, Austin KJ, Perry DJ, Pru JK, Teixeira MG, et al. (1999) Mechanism of action of interferon-tau in the uterus during early pregnancy. J Reprod Fertil 54: 329-339.

66. Spencer TE, Johnson GA, Bazer FW, Burghardt RC (2004) Implantation mechanisms: insights from the sheep. Reprod 128: 657-668.

67. Brownlie TS, Morton JM, McDougall S (2016) Accuracy of fetal age estimates using transrectal ultrasonography for predicting calving dates in dairy cows in seasonally calving herds in New Zealand. New Zealand Veterinary Journal 64(6): 324-329.

68. Choi H S, Kiesenhofer E, Gantner H, Hois J, Bamberg E (1987) Pregnancy diagnosis in sows by estimation of oestrogens in blood, urine or faeces. Animal Reproduction Science 15: 209-216.

69. Garcia A, MK Neary, GR Kelly, RA Pierson (1993) Accuracy of ultrasonography in early pregnancy diagnosis in the ewe. Theriogenology 39: 847-861.

70. Kamboj M, BS Prakash (1993) Relationship of progesterone in plasma and whole milk of buffaloes during cyclicity and early pregnancy. Tropical Animal Health and Production 25(3): 185-192.

71. Kaul V, Prakash BS (1994) Accuracy of pregnancy/non pregnancy diagnosis in zebu and crossbred cattle and Murrah buffaloes by milk progesterone determination post insemination. Tropical Animal Health and Production 26(3): 187-92.

72. Laing, JA, Heap, RB (1971) The concentration of progesterone in the milk of cows during the reproductive cycle. BrvetJ $127: 19-22$.

73. Lobago, FM Bekana, H Gustafsson (2009) Serum profiles of pregnancyassociated glycoprotein, oestrone sulphate and progesterone during gestation and some factors influencing the profiles in ethiopian borana and crossbred cattle, Reproduction in Domestic Animals 44(4): 685-692.

74. Lynch RA, BM Alexander, RG Sasser (1992) The cloning and expression of the pregnancy-specific protein B. Biol Reprod 46(1): 72. 


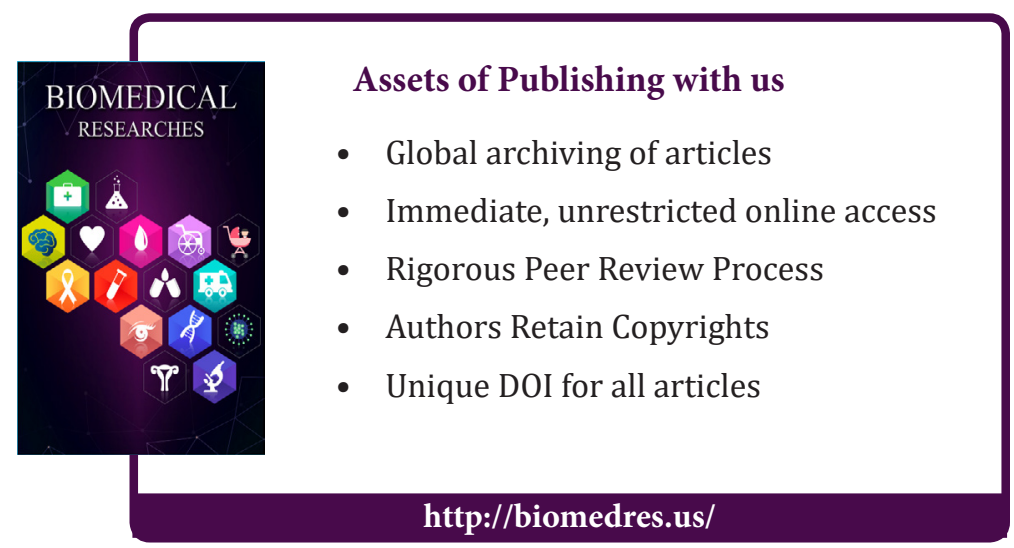

